\title{
An Overview of Key Soil Nitrogen Cycling Transformations ${ }^{1}$
}

\author{
Clayton J. Nevins, Sarah L. Strauss, and Patrick Inglett ${ }^{2}$
}

\section{Introduction}

Nitrogen $(\mathrm{N})$ is an essential element required for life. Even though $\mathrm{N}$ is the most abundant element in Earth's atmosphere, it is still one of the most limiting factors for growing plants. Nitrogen is found in multiple forms in the environment, including inorganic and organic forms (Table 1), that affect its availability for plant uptake. These forms are in a state of flux in the soil and atmosphere through biotic (microbial) and abiotic (chemical and physical) processes. The majority of fertilizers applied in Florida, by both homeowners and growers, contain N. Because of this widespread application and the critical role soils play in the availability of this $\mathrm{N}$ to plants, this article aims to provide an overview of the $\mathrm{N}$ cycle by describing key $\mathrm{N}$ transformations that result in soils gaining or losing $\mathrm{N}$. This article is intended for homeowners and growers interested in how $\mathrm{N}$ cycles within the soil.

Nitrogen can be added to soils in several ways, including decomposing plant residues, $\mathrm{N}_{2}$ fixation by soil microbes, application of water-soluble synthetic fertilizers, and atmospheric deposition. Nitrogen can also be lost from soil into groundwater or the atmosphere.

Most of the Earth's $\mathrm{N}$ is found in the atmosphere and rocks, where it is mostly unavailable for organisms to use. Nitrogen in the atmosphere is primarily in the form of dinitrogen gas $\left(\mathrm{N}_{2}\right)$ and trace forms such as nitrous oxide $\left(\mathrm{N}_{2} \mathrm{O}\right)$.
Dinitrogen gas cannot be used directly by most organisms, including plants, but it can be converted to ammonia $\left(\mathrm{NH}_{3}\right)$ through biotic and abiotic processes. Ammonia, also a gaseous $\mathrm{N}$ form, is the precursor to ammonium $\left(\mathrm{NH}_{4}^{+}\right)$; ammonium and nitrate $\left(\mathrm{NO}_{3}^{-}\right)$together comprise the main forms of $\mathrm{N}$ that are available for uptake by primary producers (including plants and algae).

Table 1. List of key inorganic and organic forms of nitrogen. (( $\mathrm{g})$ = gaseous form of nitrogen).

\begin{tabular}{|l|l|}
\hline \multicolumn{1}{|c|}{ Inorganic Nitrogen } & \multicolumn{1}{c|}{ Organic Nitrogen } \\
\hline Dinitrogen gas $\left(\mathrm{N}_{2}\right)_{(\mathrm{g})}$ & Amino acids, proteins $\left(\mathrm{NH}_{2}\right)$ \\
\hline Nitrous oxide $\left(\mathrm{N}_{2} \mathrm{O}\right)_{(\mathrm{g})}$ & Nucleic acids (DNA, RNA) \\
\hline Ammonia $\left(\mathrm{NH}_{3}\right)_{(\mathrm{g})}$ & Urea $\left(\mathrm{CH}_{4} \mathrm{~N}_{2} \mathrm{O}\right)$ \\
\hline Ammonium $\left(\mathrm{NH}_{4}^{+}\right)$ & \\
\hline Nitrite $\left(\mathrm{NO}_{2}^{-}\right)$ & \\
\hline Nitrate $\left(\mathrm{NO}_{3}^{-}\right)$ & \\
\hline
\end{tabular}

\section{Nitrogen Fixation}

Nitrogen can be directly added to the soil from the atmosphere, which is $78 \% \mathrm{~N}\left(\mathrm{~N}_{2}\right)$, through either a biological (biotic) or a physical/chemical (abiotic) process known as $\mathrm{N}_{2}$ fixation (Figure 1). One of the most common types of soil biological $\mathrm{N}_{2}$ fixation occurs when a specific group of bacteria, rhizobia, form a mutualistic relationship with legume plants, such as peanuts or clovers. Most rhizobia belong to the bacterial order Rhizobiales. Rhizobia infect legume roots and supply the plant with $\mathrm{N}$ after metabolizing $\mathrm{N}_{2}$ gas. In exchange, the rhizobia receive carbon (C)

1. This document is SL471, one of a series of the Department of Soil and Water Sciences, UF/IFAS Extension. Original publication date May 2020. Visit the EDIS website at https://edis.ifas.ufl.edu for the currently supported version of this publication.

2. Clayton J. Nevins, graduate assistant; Sarah L. Strauss, assistant professor, Department of Soil and Water Sciences, UF/IFAS Southwest Florida Research and Education Center; and Patrick Inglett, associate professor, Department of Soil and Water Sciences; UF/IFAS Extension, Gainesville, FL 32611.

The Institute of Food and Agricultural Sciences (IFAS) is an Equal Opportunity Institution authorized to provide research, educational information and other services

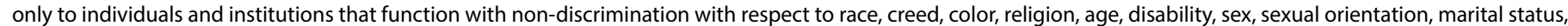

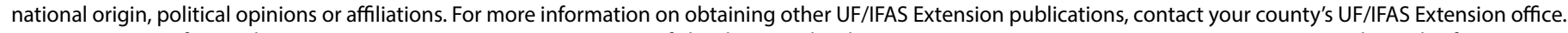
U.S. Department of Agriculture, UF/IFAS Extension Service, University of Florida, IFAS, Florida A \& M University Cooperative Extension Program, and Boards of County Commissioners Cooperating. Nick T. Place, dean for UF/IFAS Extension. 
in the form of organic acids from the legume to use as an energy source. In vegetable cropping systems, legumes are sometimes grown as a cover crop after harvest but before the next vegetable planting to help supply $\mathrm{N}$ to the soil. This $\mathrm{N}$ is then available for uptake by the cash crop following the cover crop termination. For more information on cover crops, see EDIS publication SS-AGR-66, Cover Crops (https://edis.ifas.ufl.edu/aa217).

\section{Nitrogen Fixation}

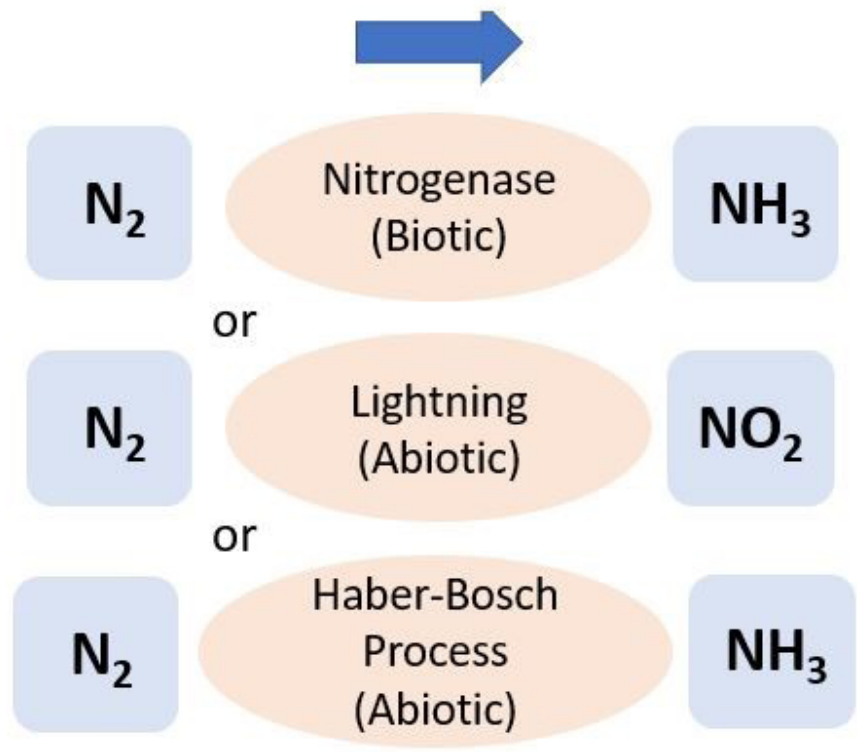

Figure 1. Nitrogen fixation is the conversion of dinitrogen gas $\left(\mathrm{N}_{2}\right)$ to ammonia $\left(\mathrm{NH}_{3}\right)$ and can be catalyzed by biotic and abiotic processes.

The industrial conversion of $\mathrm{N}_{2}$ to $\mathrm{NH}_{3}$ was developed by scientists Fritz Haber and Carl Bosch in 1909. Known as the Haber-Bosch process, this energy-intensive reaction is used worldwide to make synthetic fertilizers. The process uses very high temperatures $\left(300^{\circ} \mathrm{C}-500^{\circ} \mathrm{C}\right)$ and pressure to break apart the $\mathrm{N}_{2}$. This is done in the presence of dihydrogen and results in the formation of $\mathrm{NH}_{3}$. Ammonium nitrate $\left(\mathrm{NH}_{4} \mathrm{NO}_{3}\right)$ is a synthetic fertilizer commonly produced by the Haber-Bosch process and is a widely used $\mathrm{N}$ source for Florida crops and lawns. For more information on applying fertilizer to lawns or crops, see the EDIS documents HS1306, Fertigation for Citrus Trees (https://edis.ifas. ufl.edu/hs1306), SL-3, The Florida Fertilizer Label (https:// edis.ifas.ufl.edu/ss170), and ENH1282, The Fate of Nitrogen Applied to Florida Turfgrass (https://edis.ifas.ufl.edu/ep546).

Nitrogen can also be added to soils through atmospheric deposition. The electrical charge from lightning strikes during thunderstorms aids with the energy-intensive process of $\mathrm{N}_{2}$ fixation, and the resulting $\mathrm{N}$ falls to soil in rain. A similar process in combustion (e.g., fossil fuel burning) produces oxides of $\mathrm{N}$, which can also be deposited to land by rain. The amount of $\mathrm{N}$ from this process is small compared to what is added through $\mathrm{N}$ fertilizer, but it can be converted to plant-available forms, such as $\mathrm{NH}_{4}^{+}$ and $\mathrm{NO}_{3}^{-}$. A recent analysis reported Florida atmospheric deposition contributed approximately 2 to $3 \mathrm{~kg} \mathrm{~N} \mathrm{ha}^{-1} \mathrm{yr}^{-1}$ (Li et al. 2016).

\section{Immobilization}

Nitrogen immobilization occurs in the soil when ammonium $\left(\mathrm{NH}_{4}^{+}\right)$and nitrate $\left(\mathrm{NO}_{3}^{-}\right)$, two inorganic forms of $\mathrm{N}$, are used by soil microbes to meet their biological $\mathrm{N}$ requirements. Soil organisms play an important role in the decomposition of organic matter, such as crop residues. When residues with high $\mathrm{C}$ concentrations relative to $\mathrm{N}$ (C:N ratio) are added to soil, microbes must acquire available $\mathrm{N}$ from the soil to metabolize the $\mathrm{C}$. For example, this commonly occurs when organic material such as woody residue (e.g., sawdust) is added to a soil. The woody residue can have a C:N ratio over 100, which does not supply the soil microbial community with enough $\mathrm{N}$ to metabolize the $\mathrm{C}$ (i.e., mineralize the wood). This causes the soil microbes to remove (immobilize) almost all the normally available $\mathrm{N}$ from the soil to build their biomass. When soil microbes use this soil $\mathrm{NO}_{3}^{-}$or $\mathrm{NH}_{4}^{+}$, it is not available to plants until the microbes die and their biomass is converted back to $\mathrm{NH}_{4}^{+}$through further mineralization (see below). The rate of immobilization and the amount of $\mathrm{N}$ immobilized by the soil microbial community is determined by the starting concentrations of $\mathrm{NH}_{4}^{+}$and $\mathrm{NO}_{3}{ }^{-}$in the soil, the amount of $\mathrm{C}$ added to the soil, the size of the microbial pool, and the specific microbes present in the soil. A rule of thumb is that the risk of immobilization increases as $\mathrm{C}: \mathrm{N}$ ratios increase above 20 to 30 .

\section{Mineralization}

Nitrogen mineralization is the biological process of converting organic $\mathrm{N}$ to $\mathrm{NH}_{4}^{+}$(Figure 2). Microbes can mineralize decomposed organic material, such as crop residues, soil organic matter, or compost. Unlike biological $\mathrm{N}_{2}$-fixation, which is carried out by specific groups of microbes, $\mathrm{N}$ mineralization is less specialized and may be completed by a large variety of soil microbes. The amount of $\mathrm{N}$ mineralized to $\mathrm{NH}_{4}^{+}$depends on the $\mathrm{N}$ concentrations in the decomposing organic material and the rate at which the decomposition occurs. When soil microbes have met their $\mathrm{N}$ requirements from decomposition, excess $\mathrm{N}$ accumulates as $\mathrm{NH}_{4}^{+}$in the soil. 


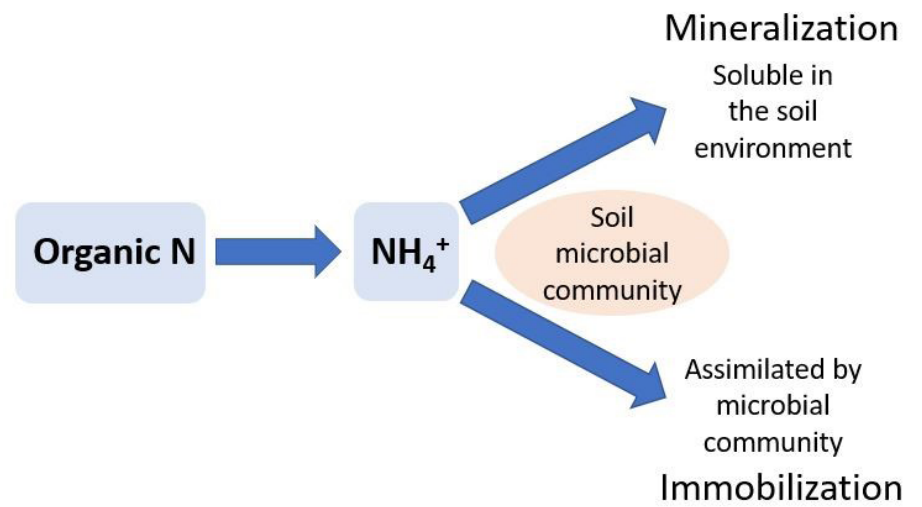

Figure 2. Organic $\mathrm{N}$ can be immobilized by the soil microbial community to meet microbial $\mathrm{N}$ demands or mineralized to ammonium $\left(\mathrm{NH}_{4}^{+}\right)$and remain soluble in the soil environment.

Organic material such as poultry manure is rich in $\mathrm{N}$, with a relatively low $\mathrm{C}: \mathrm{N}$ ratio (10:1). Alternatively, woody residue or sawdust can have high C:N ratios (200:1). See EDIS publication ENH1065, Compost Tips for the Home Gardener (https://edis.ifas.ufl.edu/ep323) for a complete list of C:N ratios. It is generally thought that approximately $50 \%$ of compost or manure will be mineralized within a year of application in Florida; however, mineralization rates depend heavily on soil type, abiotic conditions (i.e., soil temperature and moisture), and the decomposing organic material C:N. See EDIS publication SL 293, Using Composted Poultry Manure (Litter) in Mulched Vegetable Production (https://edis.ifas.ufl.edu/ss506) for more information. In general, summertime temperatures and well-drained soils with adequate moisture (near field capacity) to support good crop growth, along with a low $\mathrm{C}: \mathrm{N}$ value, will maximize mineralization rates.

\section{Nitrification}

Soil $\mathrm{NH}_{4}{ }^{+}$can be converted to $\mathrm{NO}_{3}{ }^{-}$through the process of nitrification by soil microbes, including bacteria and archaea (Figure 3). Steps include conversion of $\mathrm{NH}_{4}^{+}$to nitrite $\left(\mathrm{NO}_{2}^{-}\right)$and then to $\mathrm{NO}_{3}$. For decades it was thought that nitrification was completed by only two groups of soil bacteria: Nitrosomonas and Nitrobacter. Nitrosomonas converts $\mathrm{NH}_{4}^{+}$to $\mathrm{NO}_{2}{ }^{-}$, and Nitrobacter converts $\mathrm{NO}_{2}^{-}$to $\mathrm{NO}_{3}^{-}$. However, recent discoveries found that several other groups of soil microbes can convert $\mathrm{NH}_{4}^{+}$to $\mathrm{NO}_{2}{ }^{-}$ (ammonia-oxidizing microbes) and $\mathrm{NO}_{2}{ }^{-}$to $\mathrm{NO}_{3}^{-}$(nitriteoxidizing microbes). Nitrifying bacteria and archaea obtain energy by oxidizing the inorganic $\mathrm{N}$ compounds $\mathrm{NH}_{4}^{+}$and $\mathrm{NO}_{2}$. Furthermore, Nitrospira (a common soil resident) can complete both steps of the nitrification process $\left(\mathrm{NH}_{4}^{+}\right.$ to $\mathrm{NO}_{2}{ }^{-}$and $\mathrm{NO}_{2}{ }^{-}$to $\mathrm{NO}_{3}{ }^{-}$). Bacteria such as Nitrospira are known as comammox (complete ammonia-oxidizing) bacteria.

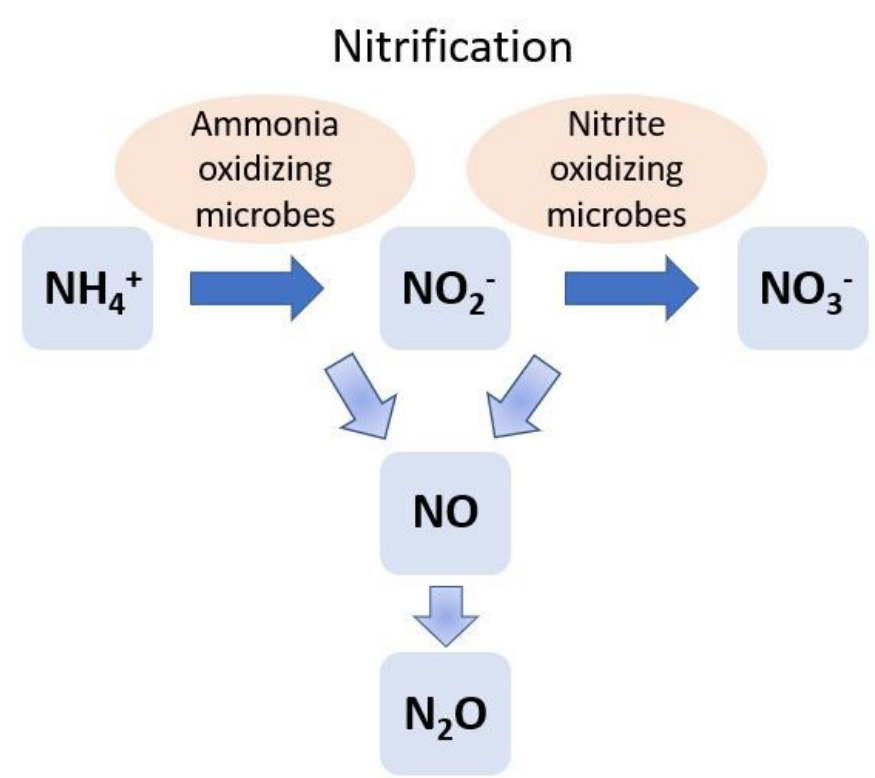

Figure 3. Nitrification is the transformation of ammonium $\left(\mathrm{NH}_{4}^{+}\right)$to nitrite $\left(\mathrm{NO}_{2}{ }^{-}\right)$and then $\mathrm{NO}_{2}{ }^{-}$to nitrate $\left(\mathrm{NO}_{3}{ }^{-}\right)$by oxidizing organisms.

Nitrification is regulated by abiotic conditions, such as soil oxygen levels and $\mathrm{pH}$, as well as soil $\mathrm{NH}_{4}^{+}$concentration. Ammonium is required for nitrification, and oxygen is required in low concentrations for the conversion of $\mathrm{NH}_{4}^{+}$ to $\mathrm{NO}_{2}^{-}$, while high $\mathrm{O}_{2}$ concentrations favor the conversion of $\mathrm{NO}_{2}^{-}$to $\mathrm{NO}_{3}^{-}$. The optimum soil $\mathrm{pH}$ for nitrification is approximately 8.0. In acidic soils, bacteria and nitrification may be inhibited. Intermediate forms of $\mathrm{N}$, such as NO, are also produced during nitrification. When conditions are ideal for nitrification, $\mathrm{NO}$ and $\mathrm{N}_{2} \mathrm{O}$ are produced in low concentrations. However, when nitrification has started but the conditions are not ideal to complete the conversion to $\mathrm{NO}_{2}^{-}$or $\mathrm{NO}_{3}$, the concentrations of $\mathrm{NO}$ and $\mathrm{N}_{2} \mathrm{O}$ increase. Lack of oxygen and acidic soils can cause the nitrification process to not be completed.

Both inorganic $\mathrm{N}$ forms, $\mathrm{NH}_{4}^{+}$and $\mathrm{NO}_{3}^{-}$, are available for plants. $\mathrm{NO}_{3}^{-}-\mathrm{N}$ is usually the most abundant soil $\mathrm{N}$ form available to plants, but it is also mobile in the soil and lost through leaching or denitrification (see below). Chemical nitrification inhibitors can be used to delay nitrification, allowing more plant-available $\mathrm{N}$ to stay in the $\mathrm{NH}_{4}{ }^{+}$form. These inhibitors are applied to the soil and interfere with nitrifying bacteria metabolism. By keeping $\mathrm{N}$ in the $\mathrm{NH}_{4}^{+}$ form longer, it may decrease the potential of $\mathrm{NO}_{3}^{-}$leaching losses. 


\section{Plant Nitrogen Uptake}

Nitrogen is removed from the soil when it is taken up by plants (Figure 4). Plant $\mathrm{N}$ requirements vary depending on the plant species, production system, and phase of growth. As mentioned previously, the $\mathrm{NO}_{3}{ }^{-}$form is typically the most abundant inorganic $\mathrm{N}$ form in the soil, but it is also more mobile. Following the 4 Rs of fertilizer management (right rate, right source, right placement, and right time) can help ensure adequate concentrations of soil $\mathrm{N}$ for plant uptake and growth while minimizing detrimental environmental impacts associated with excess mobile $\mathrm{N}$ in the soil.

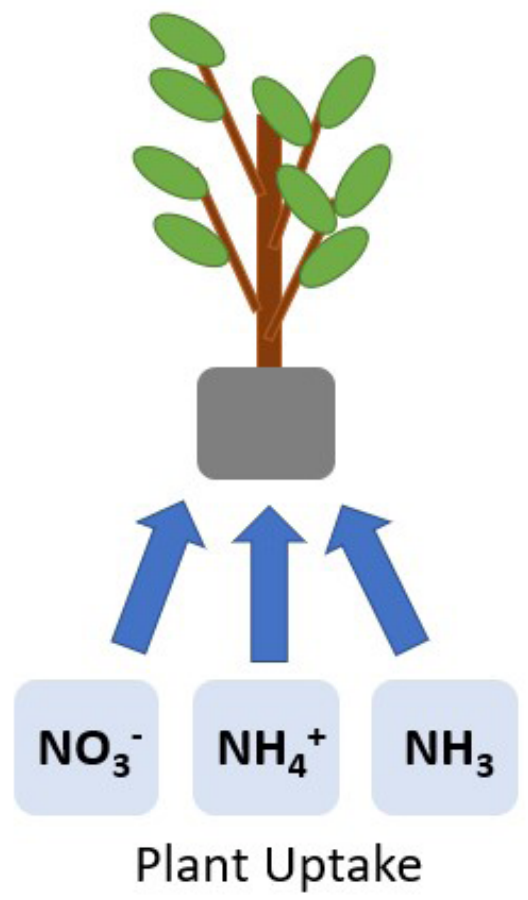

Figure 4. Nitrate $\left(\mathrm{NO}_{3}^{-}\right)$, ammonium $\left(\mathrm{NH}_{4}^{+}\right)$and ammonia $\left(\mathrm{NH}_{3}\right)$ can be taken up by plants.

\section{Denitrification}

Denitrification is the conversion of $\mathrm{NO}_{3}^{-}$to gaseous forms of $\mathrm{N}\left(\mathrm{N}_{2}\right.$ and nitrous oxide: $\left.\mathrm{N}_{2} \mathrm{O}\right)$ under low-oxygen conditions; therefore, it usually occurs in poorly drained soils (Figure 5). Like nitrification, denitrification is a process facilitated by microbes. During denitrification, anaerobic microbes obtain their energy through the conversion of $\mathrm{NO}_{3}{ }^{-}$to $\mathrm{N}_{2}$ when $\mathrm{NO}_{3}{ }^{-}$, but not oxygen, is present. Pseudomonas are commonly known denitrifying soil bacteria. The presence and abundance of these microbes depends on several abiotic factors, including soil organic matter content, $\mathrm{pH}$, moisture content, and temperature. Denitrification is less likely to be a major concern in Florida sandy soils that are generally well-drained, but it can occur if the water table is high or in soils with high organic matter, such as Histosols, which can create anaerobic conditions (Terry and Tate 1980). For example, seepage, subirrigation, or water table control irrigation can lead to saturation of the spodic layer in Florida Spodosols, leading to anaerobic conditions and increasing denitrification rates. For more information on denitrification in Florida soils, refer to EDIS article HS1004, Denitrification in SeepageIrrigated Vegetable Fields in South Florida (https://edis.ifas. ufl.edu/hs248). $\mathrm{N}_{2} \mathrm{O}$, one of the products of denitrification, is a greenhouse gas, and its production is a global concern. Agricultural soil management is the largest source of $\mathrm{N}_{2} \mathrm{O}$ emissions in the United States, accounting for $73 \%$ of total $\mathrm{N}_{2} \mathrm{O}$ emissions. However, total emissions of $\mathrm{N}_{2} \mathrm{O}$ in the United States have decreased since 1990 (EPA, https://www. epa.gov/ghgemissions/overview-greenhouse-gases).

\section{Denitrification}

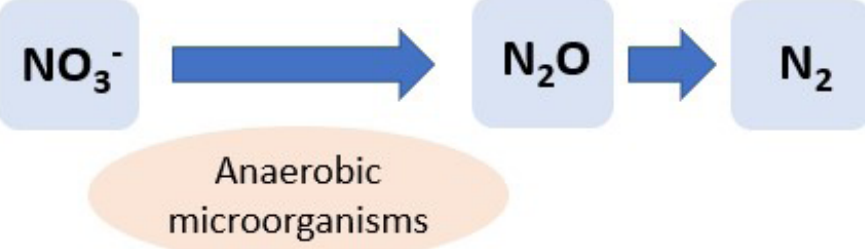

Figure 5. Denitrification is the conversion of nitrate $\left(\mathrm{NO}_{3}^{-}\right)$to nitrous oxide $\left(\mathrm{N}_{2} \mathrm{O}\right)$ and dinitrogen gas $\left(\mathrm{N}_{2}\right)$ by anaerobic microorganisms.

\section{Leaching}

One reason for the increased movement of soil $\mathrm{NO}_{3}{ }^{-} \mathrm{com}-$ pared to $\mathrm{NH}_{4}^{+}$is due to its negative charge being the same as that of many soils (clay) and organic matter. The rate of leaching in soils is driven by abiotic processes, including soil drainage characteristics and rainfall rates. Leached $\mathrm{NO}_{3}{ }^{-}$below the plant rooting zone is out of reach for plants to use. Potentially, it may leach to the groundwater or travel via soil water erosion flows into streams. Groundwater contamination with $\mathrm{NO}_{3}{ }^{-}$is a serious problem for drinking water supplies, and an influx of $\mathrm{N}$ can stimulate aquatic plant and algae growth (because it is a plant nutrient), leading to eutrophication and environmental damage. See EDIS document SGEF190, Rethinking the Role of Nitrogen and Phosphorus in the Eutrophication of Aquatic Ecosystems (https://edis.ifas.ufl.edu/sg118), for more information.

To reduce leaching, soils should not be fertilized with $\mathrm{N}$ if they are near saturation, because any additional rainfall can quickly move the plant-available $\mathrm{N}$ below the root zone. Florida soils that receive several inches of rain over a day or two might also lose most of any recently applied $\mathrm{N}$ fertilizer. In this situation, agronomic crops may require an additional $\mathrm{N}$ application to make up for the loss (Mackowiak 2014). 


\section{Volatilization}

Ammonia volatilization occurs when $\mathrm{NH}_{3}$ gas is lost to the atmosphere (Figure 6). Ammonia volatilization is controlled by abiotic processes and occurs primarily under two conditions. First, $\mathrm{NH}_{3}$ volatilization can occur when inputs of high-N organic material (urea, manure, or compost) are added to the soil. These types of inputs may raise the $\mathrm{pH}$ to greater than 8.0, creating a soil environment that prevents conversion of $\mathrm{NH}_{3}$ to $\mathrm{NH}_{4}^{+}$, allowing $\mathrm{NH}_{3}$ to escape to the atmosphere. For example, ammonia volatilization can result in $20 \%-40 \%$ of urea- $\mathrm{N}$ being lost to the atmosphere when it is applied to Florida pasturelands, and as high as $60 \%$ in Florida turfgrass systems.

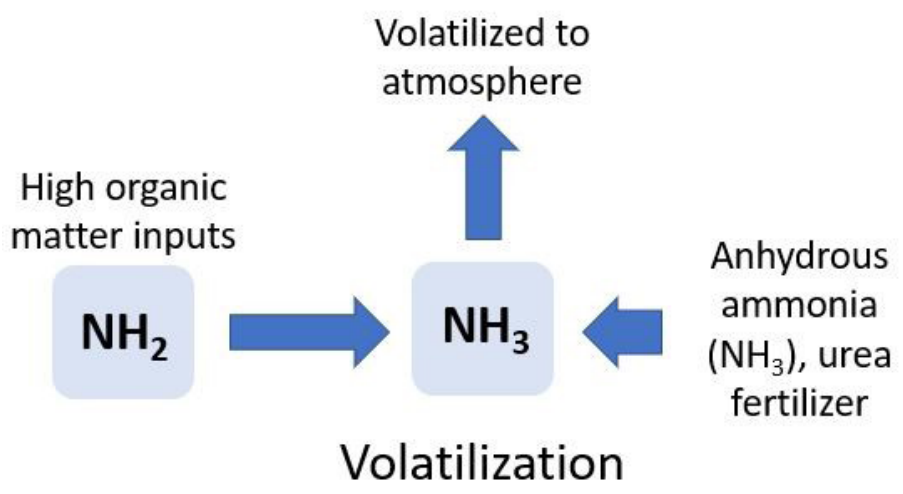

Figure 6. Ammonia $\left(\mathrm{NH}_{3}\right)$ can be volatilized when high rates of organic matter, anhydrous ammonia, or urea are added to soil.

Ammonia volatilization can also occur when anhydrous $\mathrm{NH}_{3}$ is injected into calcareous (high $\mathrm{pH},>8.0$ ) or coarse soils. Again, the high $\mathrm{pH}$ results in the conversion of $\mathrm{NH}_{4}^{+}$ to $\mathrm{NH}_{3}$, increasing the rate of $\mathrm{NH}_{3}$ volatilization. Coarse soils cannot retain the $\mathrm{NH}_{3}$ gas. The potential for $\mathrm{NH}_{3}$ volatilization also increases during periods when $\mathrm{N}$ is surface applied, air temperatures are high, and it is windy. Irrigating directly after urea- $\mathrm{N}$ applications can reduce volatilization and $\mathrm{N}$ loss because the water will move the $\mathrm{N}$ under the soil surface. Fertigation is also effective at moving $\mathrm{N}$ into the soil profile to avoid volatilization.

\section{Summary}

Although $\mathrm{N}$ is one of the most abundant elements in the biosphere, it is commonly at levels below what is needed for optimum plant growth and crop production in Florida soils. To maintain adequate $\mathrm{N}$ levels in Florida soils without detrimental environmental impact, it is useful to understand $\mathrm{N}$ cycle transformations and processes. Nitrogen transformations between organic and inorganic forms are controlled by a combination of abiotic and biotic processes. Nitrogen is added to soils from the atmosphere through abiotic and biotic $\mathrm{N}$-fixation. The biological, enzyme-driven process of mineralization adds $\mathrm{N}$ to soils when organic $\mathrm{N}$ is converted to $\mathrm{NH}_{4}^{+}$. This occurs when the $\mathrm{N}$ demand of the soil microbial community has been met. Immobilization occurs when the soil microbes use the available $\mathrm{N}$ to meet their biological $\mathrm{N}$ requirements. After mineralization, available $\mathrm{NH}_{4}^{+}$can be converted from $\mathrm{NH}_{4}^{+}$to $\mathrm{NO}_{3}^{-}$through the process of nitrification. Nitrogen can be lost from soils to the atmosphere through denitrification, a process controlled by anaerobic microbes. Nitrogen is also released from soils through leaching and volatilization. Research on the biotic and abiotic processes controlling $\mathrm{N}$ transformations will continue to advance our understanding of soil $\mathrm{N}$ cycling. For example, genomic sequencing will improve our understanding of organisms in biotic processes, and modeling will enhance the accuracy of predicting biotic and abiotic process impacts. These advances have the potential to increase environmental quality, crop production, and agriculture sustainability.

\section{References}

Li, Y., B. A. Schichtel, J. T. Walker, D. B. Schwede, X. Chen, C. M. Lehmann, M. A. Puchalski, D. A. Gay, and J. L. Collett. 2016. "Increasing Importance of Deposition of Reduced Nitrogen in the United States." Proceedings of the National Academy of Sciences 113 (21): 5874-5879.

Mackowiak, C. 2014. "Heavy Rain Causing Nitrogen Leaching in Florida." Farm Progress. https://www.farmprogress.com/management/ heavy-rain-causing-nitrogen-leaching-florida

Obreza, T., L. Parsons, and K. Morgan. 2006. Nitrogen Fertilizer Sources: What Does the Future Hold for Citrus Producers? SL238. Gainesville: University of Florida Institute of Food and Agricultural Sciences. https://edis.ifas. ufl.edu/ss457

Terry, R. E., and R. L. Tate III. 1980. "Denitrification as a Pathway for Nitrate Removal from Organic Soils." Soil Science 129 (3): 162-166. 